\title{
Yaban domuzu (Sus scrofa L.) üzerine ekolojik gözlemler ve tür habitat iliş kilerinin tespiti: Isparta-Gölcük Tabiat Parkı örneği
}

\author{
Gökhan Cengiz ${ }^{a}$, Yasin Ünal ${ }^{b, *}$, İdris Oğurluc
}

\begin{abstract}
Özet:Isparta Gölcük Tabiat Parkı'nda yayılış gösteren yaban domuzunun popülasyonu, ekolojisi ve habitat ilişkilerinin tespitini hedefleyen bu çalışma, 2011-2012 yılları arasında yapılııștır. Çalışma ön etüt, popülasyon envanteri ve habitat tercihleri olmak üzere üç aşamada gerçekleştirilmiştir. Habitat kullanımı ve habitat tercihinin belirlenmesi için Var-Yok Tarama Metodu uygulanmıştır. Toplam 106 hat ve 2655 plotta gerçekleştirilen sayımların sonuçlarına dayanan istatistiksel analizlere ve bulunan nispi frekansa göre, yaban domuzunun 17 farklı habitat tipinden hepsini de kullandığı, bunlardan en çok \%10 karaçam gençliği, \%10 sedir ormanı ve azalan oranlarla diğer ormanlık alanları kullandığı tespit edilmiştir. Yine sedir ormanı için, Multivaryasyon ve Ki-Kare Testi Analizi'nin pozit if yönde anlamlı çıkması sedir ormanının önemini arttırmaktadır Yaban domuzunun mevsimsel tercihi incelendiğinde, yalancı akasya ormanı ve ziraat alanlarını yazın daha fazla tercih ettiği, bakı tercihinde ise güney bakılara nazaran günün saatlerine göre değişen gölgelik alanları tercih ettiği gözlemlenmiştir.

Anahtar Kelimeler: Gölcük Tabiat Park1, Yaban domuzu, Habitat tercihi
\end{abstract}

\section{Ecological observation on Wild boar (Sus scrofa L.) and determination of species habitat relationships: Isparta-Gölcük Natural Park sample}

\begin{abstract}
This study, which aims to determine the population, ecology of wild boar and habitat relations spreading in the Isparta Gölcük Nature Park, conducted between the years of 2011-2012. The study is carried out in three stages such as preliminary study, population inventory and habitat preferences. In order to determine the usage of habitat and habitat preference, "Presence or Absence Method" was applied. According to the statistical analysis based on the results of counting's in totally 106 lines and in 2655 plots, and the relative frequency, showed that the wild boar uses 17 different habitat types, such as $10 \%$ the most of black pine forest, $10 \%$ cedar forest, and with decreasing rates the other forests. The positive substantive results of Multivariation and Chi-Square Test Analysis increased the importance of cedar wood. When the seasonal preference of the wild boar was analyzed, it was observed that it prefers black locust forests and agricultural fields during summer, and in the aspect preference, shadowy fields which change according to the day hours rather than South aspects.

Keywords: Gölcük Nature Park, Wild boar, Habitat preference
\end{abstract}

\section{Giriş}

Gerek mevcut yabani türlerin bir potansiyel olarak korunması ve nesillerinin devam ettirilebilmesi, gerekse tabii kaynak olarak ele alınıp bundan yararlanılabilmesi, insanın yaban hayvanlarını barındıran ekosistemleri yeterince tanıması ve ekolojik anlamda uygun yaklaşımlar geliştirmesine bağlıdır. Bir başka deyişle yaban hayvanlarının biyolojilerini bilmek yalnız başına yeterli değildir, habitat ilişkilerini de bilmek gerekir (Oğurlu, 2001).

Gölcük Tabiat Parkı (TP)'nda evvelce yapılan bir çalışmada, bu tabiat parkının Türkiye'nin önemli av hayvanlarından yaban domuzunun doğal yayılış alanı içerisinde olduğu tespit edilmiştir (Oğurlu vd., 2005). Domuz, yaptığımız bu çalışmanın hedef türünü oluşturmaktadır. Yaban hayvanlarının neslinin devam ettirilebilmesi için sürdürülen çabalar, ekosistemlerin ve dolayısıyla insanlığın geleceği bakımından önemlidir (Anonim, 1986).

Bu çalışmada, Is parta-Gölcük TP'nda domuzun ekolojik istekleri ve tür bolluk derecelerinin tespitine yönelik araştırmalar yapılmıştır. Elde edilen verilerin Yaban Hayatı Amenajman Planları'na yardımcı olabileceği düşünülmektedir.

IUCN'ye göre Yaban domuzu (Sus scrofa L.) en az risk 'LC' (Least Concern) grubundadir (IUCN Red List, 2013). 2012-2013 MAK kararına göre avlanması belirli tarihlerde serbesttir (OSB, 2013). Yaban domuzu Türkiye'de Orta ve Doğu Anadolu'da geniş step ve düzlüklerin bulunduğu birkaç il dışında her tarafta rastlanmaktadır (Kırmıt, 1991).

Geyik, karaca ve yaban domuzu gibihayvanlar gündüz sık ağaç ve ağaççıklar arasında saklanmakta, akşam saatlerine doğru otlak ve açıklıklara çıkmakta, bütün bir $\llbracket \quad{ }^{a}$ Bülent Ecevit Üniversitesi, Çaycuma Meslek Yüksekokulu, Ormancılık Bölümü, Zonguldak

b Süleyman Demirel Üniversitesi, Yaban Hayatı Ekolojisi ve Yönetimi Bölümü, Isparta

c İstanbul Ticaret Üniversitesi, Çevre ve Doğa Bilimleri Araştırma ve Uygulama Merkezi, İstanbul

@ * Corresponding author (İletişim yazarı): yasinunal@ sdu.edu.tr

$\checkmark$ Received (Geliş tarihi): 26.04.2016, Accepted(Kabul tarihi): 15.06.2016
Citation (Atıf): Cengiz, G., Ünal, Y., Oğurlu, İ., 2016. Yaban domuzu (Sus scrofa L.) üzerine ekolojik gözlemler ve tür habitat ilişkilerinin tespiti: Isparta-Gölcük Tabiat Park1 örneği. Turkish Journal of Forestry, 17(2): 158-165. DOI: $\underline{10.18182 / \mathrm{tjf} .12345}$ 
gece beslendikten sonra da sabahın ilk ışıkları ile birlikte gizlendikleri yerlere geri dönmektedirler. $\mathrm{Bu}$ nedenle gündüz saatlerinde görülmeleri kolay olmamaktadır. Oğurlu'nun belirttiği gibi; yaban hayvanlarını görmek ve doğrudan gözlemek çoğunlukla hayli zordur. Buna karşılık, hayvanın gezdiğiyerde ayak izi, dışkı gibi nesneleri görmek ise nispeten daha kolaydır. İz ve diğ er belirtiler, o alanda hangi tür hayvanların yaşadığını gösterdiği gibi, türlerin bolluk dereceleri hakkında da bir fikir verir. Ayrıca yaban hayvanları beslenme tarzları ile de kendilerini ele verirler, yani hangi tür olduklarını belli ederler. Yaban domuzu bu nedenlerden ötürü, dolaylı gözlemlerle izlenebilecek türler arasındadır (Oğurlu, 2003).

Domuzun habitat tercihine dair bazı çalışmalar yapılmıştır. Küçük ve Uslu (2004)'nun belirttiği üzere, yaşam alanında gerekli besin kaynağı bulamadığında, yerleşim yerlerindeki tarım arazilerine çeşitli zararlar vermektedir. Hızal (2007)'ın Kapıdağ Yarımadası Yaban Hayatı Koruma Alanı'nda yaptığ 1 çalışmada, domuz makilik, çöplük, ağaçlandırma sahası, tarım alanları, orman içi açıklık, yapraklı orman ve zeytinliklerde görmüştür.

Domuzun envanteri üzerine yapılmış araştırmalarda, ülkemizde domuzun normal yoğunluğu 1 birey/100 ha olarak kabuledilmektedir. Ülkemizde yaban domuzu için 10 milyon ha'llk alan olup, bu alanlarda barınabilecek domuzun sayısının 100 bin, mevcut sayının ise 80 bin olduğu tahmin edilmektedir. (Anonim, 1986).

Ünal (2011) Isparta Yazılıkaya'da yaptığ çalışmada yaban domuzunun sahadaki yoğunluğunu 5,3 birey/100 ha olarak bulmuştur. Var-Yok Metodu'na göre, domuzunun sirasıly \% 36 ormanlık alanları, \% 35 ziraat alanları, \%29 orman içi açıklıkları kullandığını bildirmiştir.

Thurfjell vd. (2009), GPS'li verici tasma takarak izlediği 17 adet domuzun ziraat alanı, ormaniçi açıklı, geniş yapraklı orman, karışık ibreli orman ve sulak alan olmak üzere 5 ana habitat tipine ayrılan araştırma sahasında yaban domuzlarının, yazın geniş yapraklı ormanları; sonbahar, kış ve ilkbaharda ise, en fazla orman içi açıklıkları kullandıklarını tespit etmiştir.

Yaban domuzlarının yaz dönemi dışında ziraat alanlarına çok az geldiği görülmektedir (Ünal 2011). Abaigar vd., (2009)'nin çalışmasına göre domuzun beslendiği yerdeki izlerinden hareketle belirtilerin multivaryasyon ve Ki-kare Testi Analizleri'ne göre, 1500 m yükseklikteki gölgelik noktaları tercih ettiğini, yamaç eğiliminin aktivitesini kısıtlamadığını, insan aktivitesinin olduğu yerlerden uzak durduğunu, yaban domuzuna ait belirtilerin en çok kıştan baş layarak, sonbahar, ilk bahar, ve en az yaz olarak görüldüğünü, meşelik ve karış ık ormanları tercih ettiğini, dere vejetasyonunu sadece beslenmek için indiğini belirtmiş tir.

Dardaillon (1986)'un Güney Fransa'da domuzun habitatta dağılımı ve tercihleri üzerine çalışmasında, 1047 ha'lık alanda altı habitat tipinde araştırma yapmış, yaban domuzlarının bataklık alanları en çok kullandığı bodur çayırları, ise bataklıklardan daha sonra kullandığ 1 ve yine akçakesme (Phillyrea sp.) alanlarını dinlenmek için, ova karaağacı(Ulmus carpinifolia) alanlarını ise sürtünmek için kullandığını, kökleme aktivitesini ise bataklıklar ve mera alanlarında yaz boyunca yaptıklarını belirtmiştir. Söz konusu çalış mada bataklık alanlarda sonbahar ve ilkbaharda yaban domuzu yoğunluğu 2,5-2,9 birey/100 ha, yazın ise 0,6 birey/100 ha bulunmuştur. Zira, yazın bataklık gibi beslenme alanları kuruyunca popülasyon komşu alanlara göç etmekte ve zirai alanlarda göç ettikleri alanlar arasında yer almaktadir.

Leaper vd. (1999) İskoçya'da yaban domuzunun genellikle meşe (Quercus sp.), sarıçam(Pinus slyvestris) ve kayınla (Fagus sp.) kaplı habitatları tercih ettiğini bulmuştur. Maksimum taşıma kapasite değerini 3-5 birey/100 ha olarak tespit etmişlerdir. Fonseca (2007)'nın Güneydoğu Polonya Karpat dağı eteklerinde domuz popülasyonunun habitat tercihi ile ilgili çalı̧̧masında, toplam alanın 47000 ha olduğu iki orman bölgesinden 21 transekt almış ve 284 km'lik bir alanı taramıştır. Bu alanlardaki domuza ait belirtileri incelemiş, domuzun Avrupa kayını (Fagus sylvatica) ve adi gürgen (Carpinus betulus), ormanlarını tercih ettiğini Avrupa göknarı (Abies alba) ormanlarını tercih etmediğini bildirmiştir.

Ülkemizde de yaban domuzunu hedef alan çeşitli araştırmalar yapılmıştır. Mesela, Is parta'nın Aksu ilçesinde yürütülen bir araştırmada, yaban domuzu (Sus scrofa)'nın yoğunluğu 0,6 birey/ha olarak tespit edilmiştir. Çalışma sahasının ağaçlık alanı 2709 ha olup, bunun avlak alanına oran1 \% 62,4'tür. Hakim ağaç türünü karaçam(Pinus nigra) oluşturmaktadır. Sahada ayrıca, meşe (Quercus sp.) ve ardıç (Juniperus sp.) ağaç türleri yayılış göstermektedir. A ğaçlık ve çalılık alan 600 ha olup, avlak alanına oranı ise \% 13,0'dır. karaçalı (Paliurus aculeatus), pırnal meşesi (Quercus aucheri), kermes meşesi (Quercus coccifera) bögürtlen (Rubus caesius) ve ahlat (Pyrus elaeagrifolia) sahanın en yaygın ağaççık ve çalı türleridir (Oğurlu ve Ünal, 2011). Kayaöz (2001) Çilingöz Yaban Hayatı Koruma Sahası'nda Yaban domuzu yoğunluğunu 9,19 birey/100 ha olarak bulmuştur. Beşkardeş vd., (2010) Bolu-Sazakiçi Örnek Avlağinda, yaban domuzu yoğunluğunu 8,03 birey/100 ha olarak tespit etmiş lerdir

Gündoğdu (2004), bir hayvan türünün habitat tercihlerine ilişkin bilgi mevcutsa bu bilgiye dayanan tahmini habitat haritaları geniş alanlardaki popülasyon seviyeleri ve yayılışları hakkında fikir verebilir demektedir. Popülasyon yoğunlukları; sahanın topoğrafyası, vejetasyon yapısı ve yol ağının sunduğu imkan dikkate alınarak uygulanacak bir "Var-Yok Taraması" ile alan bazında belirlenebilmektedir. $\mathrm{Bu}$ sebeple de yaban hayat1 envanterinin, planlama sürecinde en azbir kez tekrarlanmas1 gerekmektedir (Oğurlu, 2008). Yaban domuzu üzerine yaptığımız ekolojik gözlemlerde türün habitat tercihi kestirilmesi amaciyla Gölcük TP'nda yürüttüğümüz bu çalışma ülkemizde yürütülmesi düşünülen benzer çalışmalar için bir örnek ve literatür teşkil etmesi açısından önem taşıyacağı düşünülmektedir.

\section{Materyal ve yöntem}

\subsection{Materyal}

Çalışma alanımız olan Gölcük TP, Doğa Koruma 6.Bölge Müdürlüğü sinırları içinde mevcut olup Tabiat parklarımız içinde büyüklük bakımından 4. sırada yer almaktadır (DKMPGM, 2012; OSB 6. BÖLGE, 2012). Göl ve çevresinin sahip olduğu bitki örtüsü, yaban hayat1, jeomorfolojik yap1, peyzaj güzellikleri ve rekreasyon imkanlarından dolayı, 1991 yılında Bakanlık Olur'u ile Tabiat Parkı ilan edilmiştir. Bu nedenlerden dolayı 5.925 hektar büyüklüğündeki Gölcük TP jeomorfolojik yapısı ve 


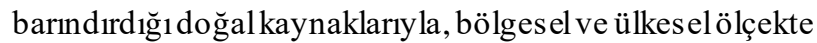
önemli bir konumda yer almaktadır (IIÇOM, 2006; IİÇOM, 2010).

Gölcük Tabiat Parkı, Batı Akdeniz Bölgesi’nde Isparta Merkez ilçenin güney batısında yer almaktadır. $1380 \mathrm{~m}$ rakımlı ve çevresi ağaçlandırılmış bir krater gölü olan Gölcük TP, şehir merkezine $12 \mathrm{~km}$ uzaklıktadır. Kentin güney batısinda, $37^{\circ} 41^{\prime} 04^{\prime \prime}$ - $37^{\circ} 45^{\prime} 03^{\prime \prime}$ kuzey enlemleri ve $30^{\circ} 27^{\prime} 40^{\prime \prime}$ - $30^{\circ} 35^{\prime} 33^{\prime \prime}$ doğu boylamları aras ındadır. Küçük bir krater gölü olan Gölcük Gölü, deniz yüzeyinden 1378 metre yükseklikte olup, yüzölçümü 76 hektar ve kıy1 uzunluğu ise 3.647 metredir (Kultur, 2010; IIÇOM, 2006). Sahanın yeri genel morfolojik özellikleri incelendiğinde Gölcük Gölü, Güneybatı Anadolu'nun tek kaldera gölüdür. Ayrıca alanda aşınım yüzeyleri ve piroklastik dolgu yüzeyleri mevcuttur (IIÇOM, 2006). Bu piroklastik dolgu alanları yaban hayvanların besin ihtiyacını karşılamada önem arz etmektedir.

Gölcük TP'nda mevcut habitatların alan bazında orman (3.909 ha), tarım (449,5 ha), çalılık (944 ha), kayalık (513 ha), Göl (76 ha), yollar (33,5 ha) toplamda 5925 ha alana sahiptir (IIÇOM, 2006). Doğal bitki örtüsü akçakesme, tespih çalısı, laden, katırtırnağı ve geven gibi çok yıllık bitkilerle çeşitli otsu bitkiler iken karaçam, sarçam, sedir ve yalancı akasya plantasyonlarıyla saha ağaçlandırılmıştır (IIÇOM, 2007). Vejetasyon tiplerinde orman vejetasyonunda Pinus nigra, Cedrus libani ve Robinia pseudoacacia saf ve karışı ormanlarla, çalı vejetasyonu Quercus coccifera L. ve Quercus robur L., tarm alanları geçmişte yörede yaşayan halk tarafindan dikilen Malus sylvestris ve Pyrus elaeagnifolia türleri ve terk edilmiş alanlar, step alanları ve kayalık alanlar mevcuttur (IIÇOM, 2006).

Domuzun ekolojisi ve tür bolluk derecelerin tespiti için, çalışma alanına ait altlık haritaları olan topoğrafik ve meşcere tipleri haritaları kullanılmıştır. Hazırlanan arazi kartına habitat bilgileri ve domuzun varlı̆gna ait belirtiler, Var-Yok gözlem kartına; gece gözlemleri ise gece gözlem kartına işlenmiştir. Şekil 1'de Gölcük Tabiat Parkı ve araştırma yapılan alanlar gösterilmiştir.

\subsection{Yöntem}

2011-2012 yılları arasında yapılan çalışma ön etüt, popülasyon envanteri, türün ekolojisiyle ilgili olarak habitat tercihlerinin ve habitat ilişkilerinin belirlenmesine yönelik kaydedilen verilerin büro ortamında değerlendirilmesi olmak üzere üç aşamada gerçekleştirilmiştir. Ön etüt aşamasında literatür taraması yapılmış ve arazide kullanılacak topoğrafik haritalar elde edilmiştir.

Bu çalışmada, Isparta-Gölcük TP'nda domuzun habitat isteklerini belirlemek ve habitat ilişkilerini tahmin etmek için, sahada yayılış gösteren domuzun varlığı, envanter süresince kullanılacak sahanın yol ağı durumu, sahanın genel jeolojik yapısı gibi bilgilere ulaşılmıştır. Habitat tercihlerinin tespiti amaciyla özellikle yol ağı merkezli ve sistematik olarak alınan 106 sayımhattı güzergâhında ve 17 farklı habitat tipinde Var-Yok Tarama Metodu uygulanmıştır. Bu habitatlar; OR ÇK: Karaçam Ormanı, OR S: Sedir Orman1, OR AK: Yalanc1 Akasya Orman1, OR KAR (ÇK, AK): Karaçam-Yalancı Akasya Karışık Ormanı, OR KAR (ÇK, S): Karaçam-Sedir Karışık Ormanı, OR KAR (S, AK): Sedir-Yalancı Akasya Karışık Ormanı, OR
GENÇ ÇK: Karaçam Gençliği, OR GENÇ S: Sedir Gençliği, OİA: Orman İçi Açıklılar, ST AÇ: Step Açılıklar, ÇALI ST: Çalı-Step Alanlar, YOL: Yol Alanları, ZIRAAT: Ziraat Alanları, MAKİ: Makilik, KAY: Kayalık, DERE VEJ: Dere Vejetasyonu, GÖL K: Göl Kenarı diye ayrılmıştır.

Çalışmada, yaban hayvanlarının varlığı hakkında ve habitat seçimleri bazında fikir edinebilmek ve her bir sayım hattına 20'şer m aralıklarla r=114 cm yarıçapında dairelerde domuza ait belirtilere ulaşabilmek amacıyla, taramalar yaparak toplam 2655 adet plotta arazi çalış ması yapılmıştır.

Böylelikle $53.100 \mathrm{~m}$ uzunluktaki bir hat üzerinde 10.834,38 $\mathrm{m}^{2}$ lik örnek alan taranmıştır (Oğurlu, 1992). Taranan alanlar 1/25000'lik topografik harita üzerine işaretlenip, daha sonra bu veriler büro ortamında sayısal haritalara geçirilmiştir.

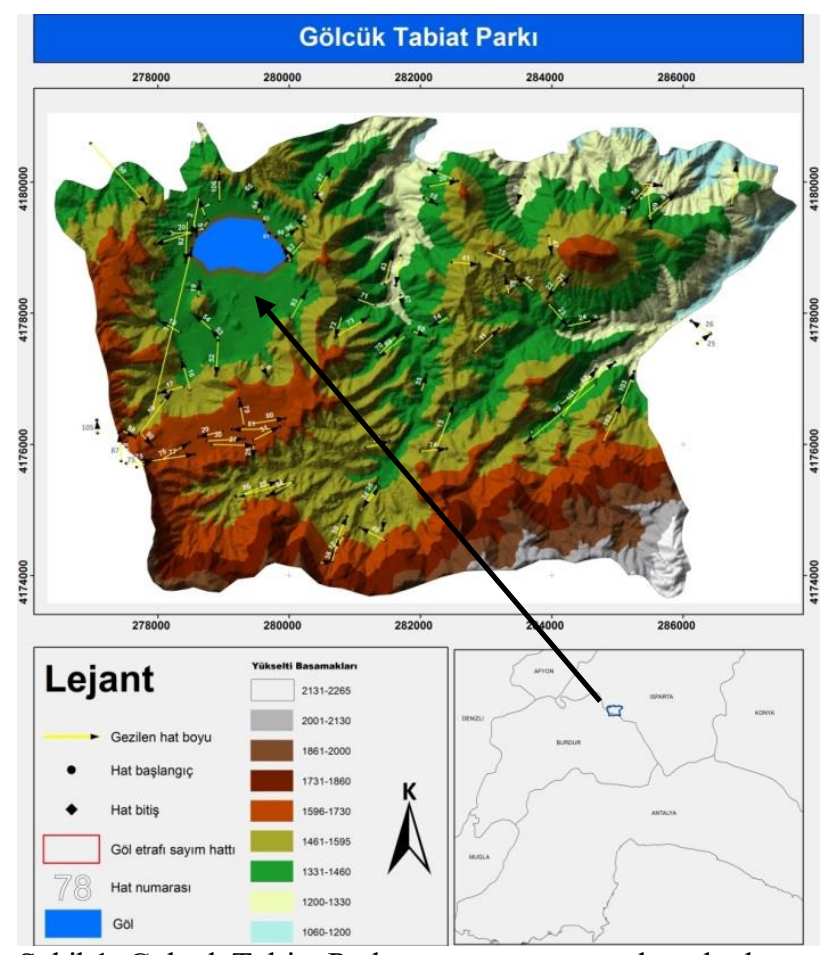

Şekil 1. Gölcük Tabiat Parkı ve araştırma yapılan alanlar

Elde edilen veriler;

1. Habitat tipi ve tüm çalışma bazında hesaplanan iz-belirti değerlerine bölünerek, ayrı ayrı Nispi Kullanım İndisi (Katsay1s1) NFİ $=F_{1} / F$ formülüne göre belirlenmiştir.

Burada,

$\mathrm{F}_{1}=$ Belirli bir habitat tipinde kaydedilen frekans = Habitatta görülen belirti sayısı / Habitatın plot sayıs1

$\mathrm{F}=$ Saha genelinde rastlanan frekans $=$ Toplam belirti sayıs1 / Toplam plot sayıs1

2. Çalışmada elde edilen veriler değerlendirilirken tanımlayıc1 is tatistiks el metotları (frekans, yüzde, toplam, ortalama) uygulanmış, iz ve belirti görülme sıklı̆̆ arasındaki ilişkileri saptamak içinde SPSS 17 programında 
Korelasyon analizi ve Ki- kare testi kullanılmıştır. Sonuçlar $\% 95$ güven aralığında, anlamlılı $\mathrm{p}<0,05$ düzeyinde çift yönlü olarak değerlendirilmiştir.

\section{Bulgular}

Domuzun 17 farklı habitat ve 2655 plotta nispi kullanım indisi Çizelge 1'de, farklı habitatları tercihi ise Şekil 2'de verilmiştir.

Çizelge 1. Yaban domuzunun habitat nispi kullanımı

\begin{tabular}{|c|c|c|c|c|c|}
\hline Habitat tipi & Plot sayis1 & İz belirti sayıs1 & Habitat frekans1 $\left(F_{1}\right)$ & Genel frekans (F) & Habitat nispi kullanım indisi (NFI) \\
\hline OR ÇK & 232 & 66 & 0,284 & 0,211 & 1,346 \\
\hline OR S & 126 & 50 & 0,397 & 0,211 & 1,878 \\
\hline OR AK & 167 & 59 & 0,353 & 0,211 & 1,672 \\
\hline OR KAR (CCK,AK) & 15 & 2 & 0,133 & 0,211 & 0,631 \\
\hline OR KAR(ÇK,S) & 61 & 23 & 0,377 & 0,211 & 1,784 \\
\hline OR KAR(S,AK) & 6 & 1 & 0,167 & 0,211 & 0,788 \\
\hline OR GENÇ ÇK & 24 & 10 & 0,417 & 0,211 & 1,972 \\
\hline OR GENÇ S & 126 & 31 & 0,246 & 0,211 & 1,164 \\
\hline Oİ & 330 & 83 & 0,252 & 0,211 & 1,191 \\
\hline ST AÇ & 348 & 74 & 0,213 & 0,211 & 1,006 \\
\hline ÇALI ST & 285 & 40 & 0,141 & 0,211 & 0,664 \\
\hline YOL & 101 & 29 & 0,287 & 0,211 & 1,359 \\
\hline ZİRAAT & 78 & 14 & 0,179 & 0,211 & 0,849 \\
\hline MAKİ & 210 & 35 & 0,167 & 0,211 & 0,789 \\
\hline KAY & 52 & 7 & 0,135 & 0,211 & 0,637 \\
\hline DERE VEJ & 134 & 29 & 0,216 & 0,211 & 1,024 \\
\hline GÖL K & 360 & 8 & 0,022 & 0,211 & 0,105 \\
\hline
\end{tabular}

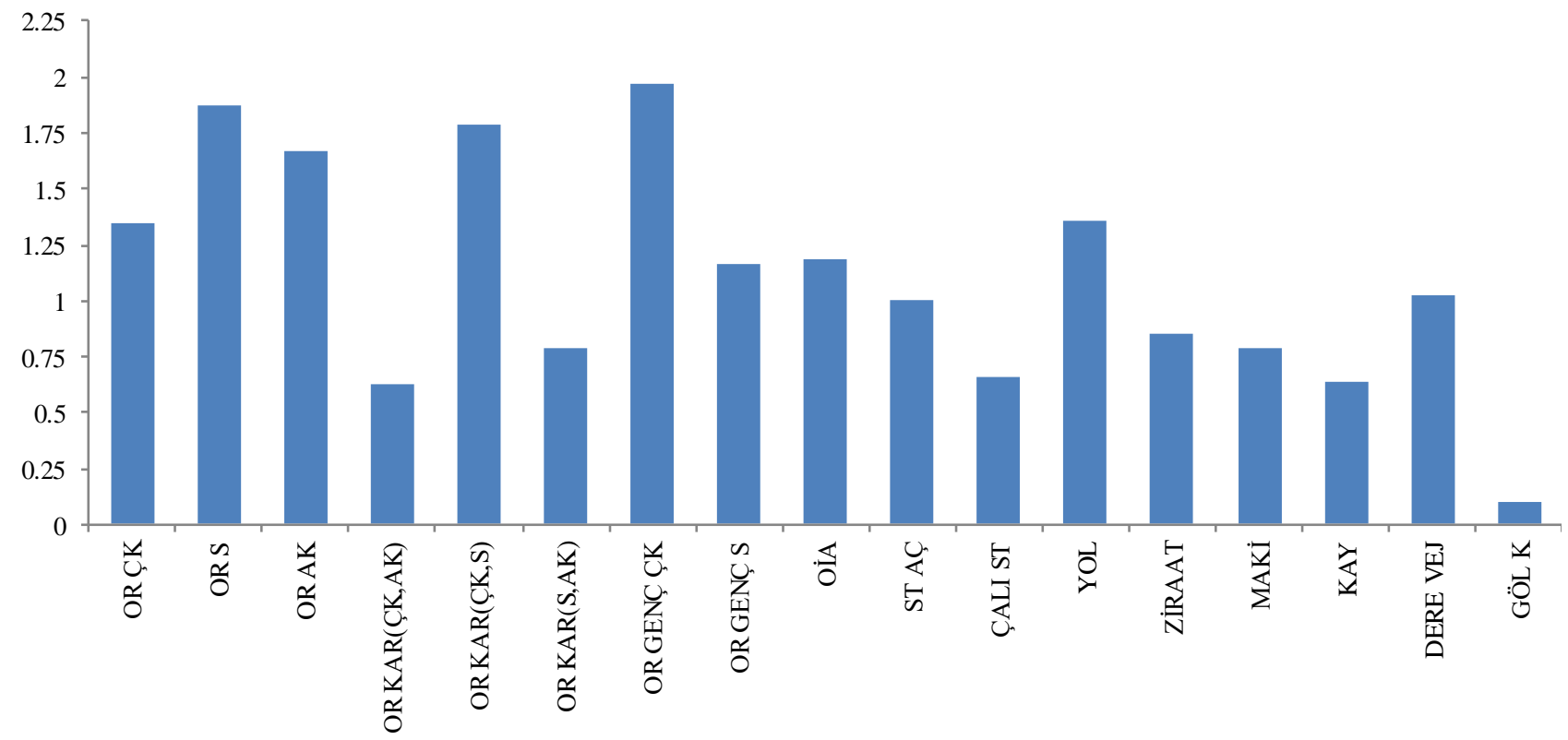

Şekil 2. Yaban domuzunun habitat tercihi 
Arazi çalışmalarında incelenen hatlardaki 17 habitat tipinden 12 tanesinde dört mevsim çalışma yapılmış ve domuzun habitat tiplerine göre mevsime bağlı habitat tercihleri bulunmuştur. Bunların mevsim NFİ Çizelge 2'de mevsime bağlı habitat tercihleri Şekil 3,4,5,6,7,8'de verilmiştir.

Yaban domuzu için yapılan arazi çalışmalarında, inceleme yapılan hat güzergâhlarında tüm bakılardan nokta alınmış ve bakıların nispi kullanım indisi karşılaştırılmıştır. Yaban domuzunun bakı tercihi, elde edilen veriler analiz edilerek Çizelge 3'de frekansları, Şekil 9'da bakı tercihleri saptanmıştır.

Çizelge 2. Mevsim Nispi Frekans İndisi (NFI)

\begin{tabular}{lcccc}
\hline Habitat Tipi & $\begin{array}{c}\text { K1ş } \\
\text { NFI }\end{array}$ & $\begin{array}{c}\text { Ilkbahar } \\
\text { NFI }\end{array}$ & $\begin{array}{c}\text { Yaz } \\
\text { NFI }\end{array}$ & $\begin{array}{c}\text { Sonbahar } \\
\text { NFI }\end{array}$ \\
\hline OR ÇK & 0,845 & 1,480 & 1,438 & 0,703 \\
OR S & 0,840 & 0,344 & 1,176 & 1,136 \\
OR AK & 0,657 & 0,885 & 1,490 & 1,155 \\
OR KAR(ÇK,S) & 1,447 & 0,663 & 1,105 & 1,137 \\
OR GENÇ S & 0,313 & 1,517 & 0,938 & 0,203 \\
OİA & 0,723 & 0,973 & 1,029 & 1,144 \\
ST AÇ & 0,504 & 1,259 & 1,242 & 0,840 \\
ÇALI ST & 0,656 & 1,451 & 1,696 & 1,096 \\
YOL & 0,000 & 0,903 & 2,522 & 0,268 \\
ZİRAAT & 0,464 & 1,071 & 1,444 & 0,000 \\
KAY & 0,000 & 1,238 & 2,122 & 0,000 \\
DERE VEJ & 0,705 & 1,540 & 0,924 & 1,275 \\
\hline
\end{tabular}

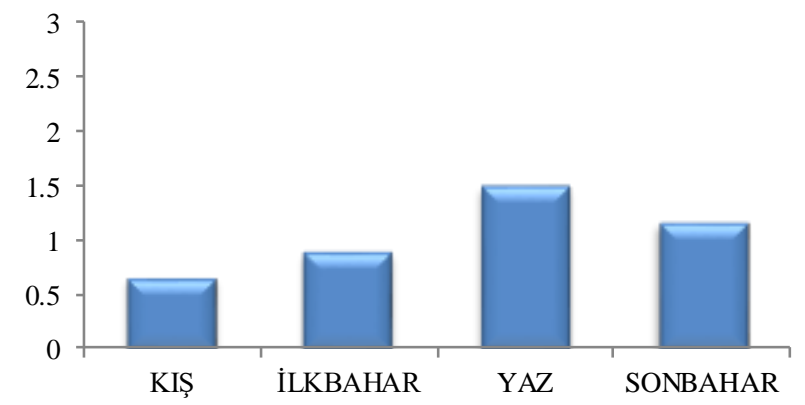

Şekil 3. Yalancı Akasya ormanı mevsime bağlı habitat tercihi

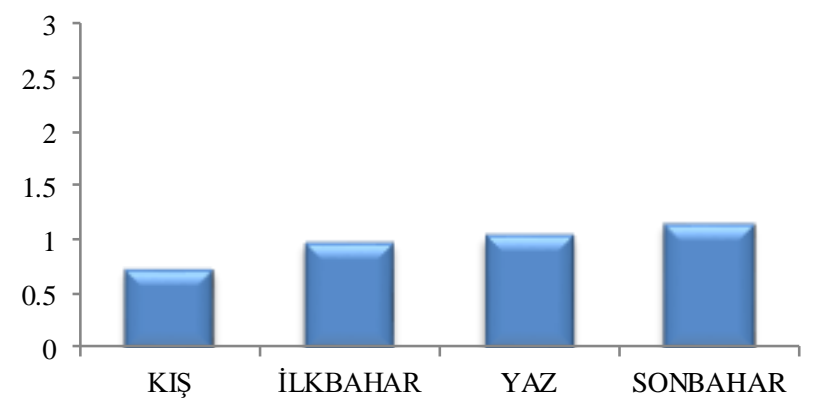

Şekil 4. Orman içi açıklıklar mevsimse bağlı habitat tercihi

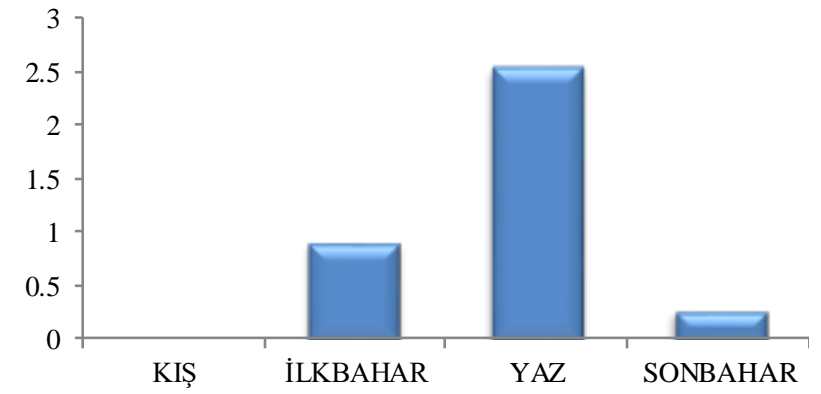

Şekil 5. Yol alanları mevsime bağlı habitat tercihi

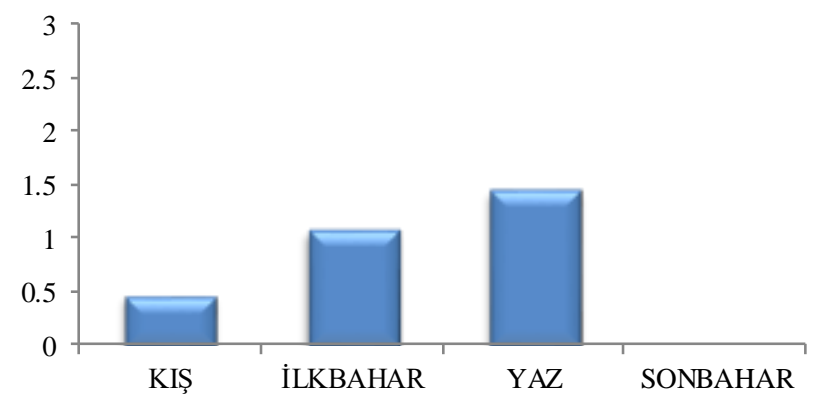

Şekil 6. Ziraat alanlanı mevsime bağlı habitat tercihi

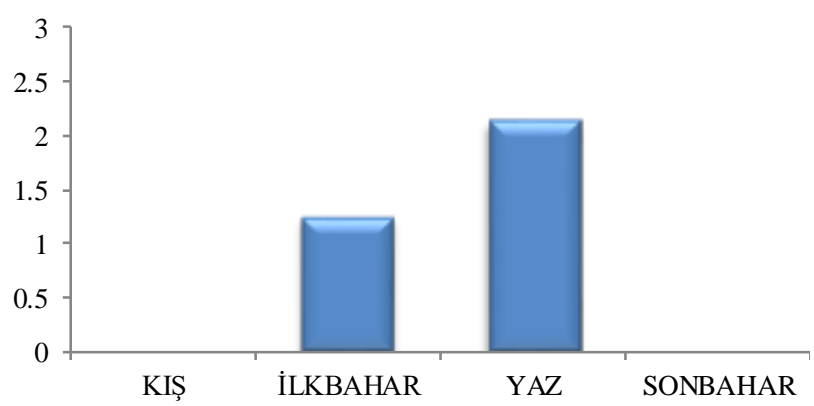

Şekil 7. Kayalık alanlar mevsime bağlı habitat tercihi

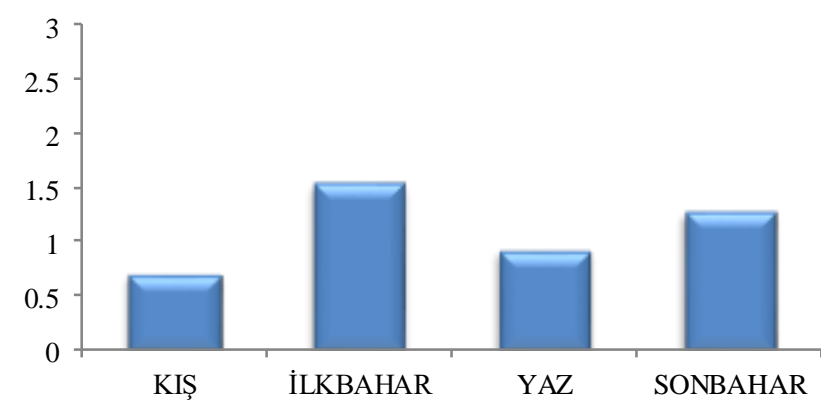

Şekil 8. Dere vejetasyonu mevsime bağ lı habitat tercihi 
Çizelge 3. Yaban domuzunun bakılardaki nispi frekans1

\begin{tabular}{lccc}
\hline Bak1 & Bak1 frekans1 & Genel frekans1 & Nispi frekans1 \\
\hline Kuzey & 0,077 & 0,245 & 0,316 \\
Kuzey doğu & 0,264 & 0,245 & 1,081 \\
Doğu & 0,239 & 0,245 & 0,974 \\
Güney doğu & 0,371 & 0,245 & 1,513 \\
Güney & 0,186 & 0,245 & 0,759 \\
Güney bat1 & 0,264 & 0,245 & 1,077 \\
Bat1 & 0,282 & 0,245 & 1,153 \\
Kuzey bat1 & 0,221 & 0,245 & 0,901 \\
\hline
\end{tabular}

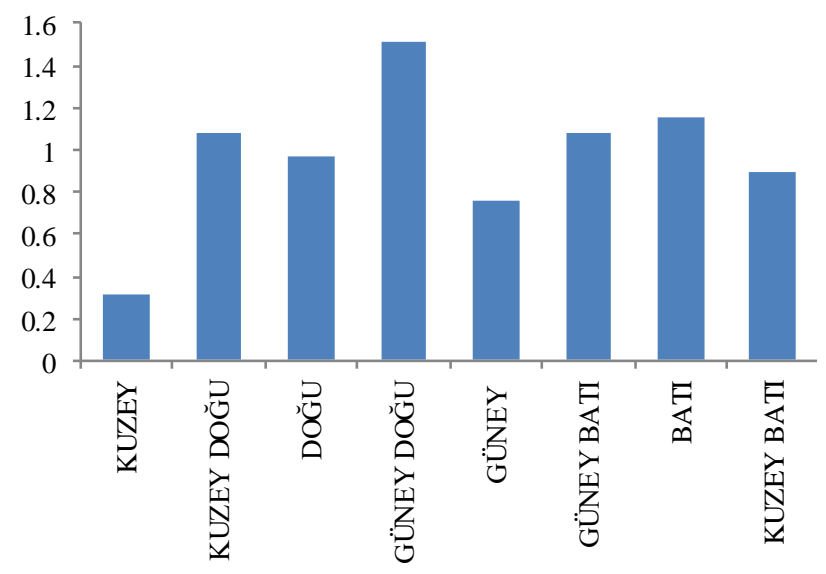

Şekil 9. Yaban domuzunun bakı tercihi

Var-Yok Taraması'nın istatistikî değerlendirmesi için, tespit edilen iz ve belirtilerin habitat tiplerindeki görülme sıklığının hesaplanması amaciyla SSPS 17 istatistik programında Sperman Korelasyon Analizi uygulanmış, ayrıca veriler Ki-kare Testi'ne tabi tutulmuş, istatistiki iliş kiler Çizelge 4'de gösterilmiştir.

Buna göre yaban domuzu için Sedir ormanının değişkeninin çizelge 4'de görüldüğü üzere (p: $0,041<0,05)$ önem seviyesi 0,041 çıkmıştır. Aynı şekilde çizelge 4'de incelendiği zaman, kayalık alanların değişkeninin önem seviyesi değeri $0(p=0<0,05)$ olduğu görülmüştür.

\section{Tartışma}

Araştırma yöntemimiz, Var-Yok verilerine dayandığ 1 için bu verilere dayanarak yaban domuzunun çalışma alanı içerisindeki yayılışını ve hangi alanları tercih ettiği söylemek kolayca mümkündür. Ancak, Gündoğdu (2004)'un bildirdiği üzere, eğer arazide hayvanların görüldüğü noktalar habitat haritaları üzerinde işaretlenirse, hayvan türlerinin habitat tercihlerine ilişkin temel bilgiler kabaca elde edilmiş olur; fakat hayvan türleri için çok önemli olan habitat özellikleri detaylandırılarak tanımlanamaz. Buradan hareketle, sahada kaydedilen veriler yaban domuzunun habitat kullanımı ve habitat tercihlerini gösterecek şekilde ortaya konmuştur.

Gölcük TP'nda yaban domuzunun ekolojisi ve tür habitat iliş kileri üzerine araştırma yaptığımız bu çalışmada, domuzun habitat tercihleri, tespit edilen 17 habitatın 12'sindeki mevsim tercihi, bak1 tercihi mevcut literatürle yapılan karşılaştırma aşağıda gösterilmiştir.

$\mathrm{Bu}$ çalışma, Ünal (2011) ve Hızal (2007)'ın memeli envanteri ve ekolojisi, Oğurlu ve Ünal (2011)'in yaban domuzu envanterinden sonra yürütülen en kapsamlı çalışmadır.
Çizelge 4. Yaban domuzuna ait habitat is tatistik değerleri

\begin{tabular}{lcccc}
\hline \multirow{2}{*}{ Habitat } & \multicolumn{2}{c}{ Sperman korelasyon analizi } & \multicolumn{2}{c}{ Ki-kare testi } \\
\cline { 2 - 5 } & $\begin{array}{c}\text { Korelasyon } \\
\text { katsay1S1 }\end{array}$ & $\begin{array}{c}\text { Onem } \\
\text { seviyesi }\end{array}$ & $\begin{array}{c}\text { Ki-kare } \\
\text { değeri }\end{array}$ & $\begin{array}{c}\text { Onem } \\
\text { seviyesi }\end{array}$ \\
\hline ORÇK & 0,113 & 0,066 & $3,393^{\mathrm{a}}$ & 0,065 \\
OR S & $0,126^{*}$ & 0,041 & $4,163^{\mathrm{a}}$ & 0,041 \\
OR AK & 0,075 & 0,226 & $1,475^{\mathrm{a}}$ & 0,225 \\
OR ENÇ ÇK & 0,074 & 0,232 & $1,441^{\mathrm{a}}$ & 0,230 \\
OR GENÇ S & 0,085 & 0,170 & $1,898^{\mathrm{a}}$ & 0,168 \\
OİA & $-0,019$ & 0,759 & $0,095^{\mathrm{a}}$ & 0,758 \\
ST AÇ & $-0,085$ & 0,168 & $1,909^{\mathrm{a}}$ & 0,167 \\
ÇALI ST & 0,016 & 0,800 & $0,065^{\mathrm{a}}$ & 0,799 \\
YOL & $-0,111$ & 0,072 & $3,255^{\mathrm{a}}$ & 0,071 \\
ZİRAAT & $-0,067$ & 0,276 & $1,198^{\mathrm{a}}$ & 0,274 \\
MAKİ & 0,085 & 0,170 & $1,898^{\mathrm{a}}$ & 0,168 \\
KAY & $-0,216^{* *}$ & 0,000 & $12,306^{\mathrm{a}}$ & 0,000 \\
DERE VEJ & $-0,041$ & 0,507 & $0,444^{\mathrm{a}}$ & 0,505 \\
GÖL K & 0,085 & 0,166 & $1,929^{\mathrm{a}}$ & 0,165 \\
\hline
\end{tabular}

Çalışmada yaban domuzunun 17 farklı habitat tipinden hepsini de kullandığ 1 , bunlardan en çoktan en aza doğru sırasıyla \% 10 karaçam gençliğini, \%10 Sedir ormanını, \%9 Karaçam-Sedir karışık ormanını, \%9 Yalancı Akasya ormanını, \%7 Karaçam ormanını, \%7 Yol alanlarını, \%6 Orman içi açıklık alanlarını, \%6 Sedir gençliğini, \%5 Ziraat alanların1, \%5 Dere vejetasyonunu, \%5 Step açıklıkların1, \% 4 Çalı-step alanlarını, \%4 Makilik alanlarını, \%4 SedirYalancı Akasya karışık ormanını, \%3 Karaçam-Yalancı Akasya karışık ormanını, \%3 Kayalık alanlarını ve \%1 Göl kenarını tercih ettiği görülmüştür.

Ünal (2011)'ın Isparta Yazılıkaya'da yaptığı çalışmaya paralel şekilde, araştırmamızdaki habitat tercihinde de en çok kullanılan habitat tipinin ormanlık alanlar olduğu ortaya çıkmıştır. Yaban domuzunun karaçam gençliğini daha fazla tercih etmesi bu alanlarda hem gizlenme hem de habitatın otsu bitkileri bakımından daha zengin olması dolayıs 1yladır. Dardaillon (1986)'un Güney Fransa'da domuzun habitatlarda dağılımı ve tercihleri üzerine çalışmasında domuzun bataklık alanları tercih ettiğini belirtmiştir Genel literatürde de domuzun sulak arazileri tercih ettiği bilinmektedir. Ancak çalışmamızda göl kenarı tercihinin düşük çıkmas ının nedeni, TP'nda rekreasyonun yani insan aktivitesinin en çok olduğu alanlar olduğunun tespit edilmesidir. Burada gündüzve gece piknik, yürüyüş ve olta balıkçılığı yapılmaktadır. Bu da domuzun göl kenarından uzak durmas ina neden olmaktadır.

Dere vejetas yonu kullanma dereces inin düşük olmasının nedenleri ise, mevcut alanda derelerin kuru dere olmasıdır. Derelerin mevcut kaynak suları borularla Isparta iline su kaynağ1 olarak getirilmektedir. Bu da domuzun varlığını tehdit etmektedir. Alanda daima akan Darı deresinin üzerinde baraj olması ve burada ins an yerleşimi olması, bu alanlarda domuzun aktivitesini kıs itlamaktadır. Ayrıca Darı Deresi habitat bakımından makilik, yani kermes meşesi alanlarına sahiptir. Bu alandaki kermes meşesinin s 1k olmas 1 domuzun alanı kullanımını kısıtlamaktadır.

Çalışmada yaban domuzunun farklı habitat tiplerinde mevsim tercihi incelendiğinde, Yalancı Akasya ormanını $\% 36$ yaz ve \%27 sonbaharda, Orman içi açıklık alanlarını \% 29 sonbahar ve $\% 25$ yazın, Yol alanların $\% 68$ yaz ve $\% 25$ ilkbaharda, Ziraat alanlarm $\% 48$ yaz ve \%36 ilkbaharda, Kayalık alanlarını \%63 yaz ve \%37 ilkbaharda, Dere vejetasyonunu $\% 34$ ilkbahar ve $\% 29$ sonbaharda tercih ettiği saptanmıştır. 
Thurfjell vd. (2009)'nin yaban domuzunun habitat tercihini belirlemek amacıyla yaptı̆̆ 1 çalışmada, bulduğumuz değerlere benzer değerler bulunmuştur. Çalışma sonuçlarında domuzun geniş yapraklı ormanları yazın tercih ettiği ifade edilmiş, bizimde buna paralel olarak alanımız içinde bulunan Yalancı Akasya ormanını domuzun en çok \%36 değerle yazın tercih ettiği gözlemlenmiştir. Sonbahar, kış ve ilkbaharda ise, en fazla orman içi açıklıkları kullandıklarını tespit etmişlerdir. Gölcük TP'nda ki çalışmada ise domuzun orman içi açıklıları her mevsim birbirine yakın değerde kullandığ 1 bulunmuştur. Abaigarvd. (2009)'nin çalışmasına göre yaban domuzu beslenme ihtiyacını genellikle dere vejetasyonlarında karşılamaktadır. Çalışmamı da, aynı yönde sonuç elde edilmiş ve yaban domuzunun dere vejetasyonunu dört mevsimbirbirine yakın değerlerde kullandığ 1 saptanmıştır.

Dardaillon (1986)'un Güney Fransa'da domuzun habitatta dağılımı ve tercihleri yapılan üzerine çalışmasında yazın bataklık alanlar kuruduğunda yaban domuzun yakın civardaki zirai alanlara göç ettiğini bildirmiş, çalışmamızda da domuzun zirai alanları kullanım oranı yazın \% 48 gibi nispeten yüksek bir değer çıkmıştır. Bu da Küçük ve Uslu (2004)'nun belirttiği üzere, ülkemizin yaşam alanında gerekli besin kaynağ 1 bulamadığında, yerleşim yerlerindeki tarım arazilerine çeşitli zararlar vermesine neden olduğunu doğrulamaktadır. Ayrıca domuzun kayalık alanları kullanımı sonbahar ve ilkbaharda gözlenmemiştir. Bunun sebebi ise, bu alanlarda devamlı vejetasyonun olmayışıdır. $\mathrm{Bu}$ alanlardaki otsu türler ilkbaharın gelmesiyle yeşillenmektedir. $\mathrm{Bu}$ nedenle yaban domuzu bu alanlan yazın en çok kullanmaktadır. Ayrıca \%68 Yol alanlarını yazın tercih etmesi önem arz etmektedir.

Çalışmada, Yaban domuzunun bakı tercihi incelendiğinde güney doğuyu \% $\%$, batıy $\% 15$, güney batıy $\% 14$, kuzey doğuyu \% 14, doğuyu \% 12, kuzey batıy $\% 12$, güneyi $\% 10$, kuzeyi $\% 4$ tercih ettiği saptanmıştır.

Abaigar vd., (2009)'nin çalışmas inda domuzun, $1500 \mathrm{~m}$ yükseklikteki gölgelik noktaları tercih ettiğini bildirmiştir. Çalışmamız bahsi geçen çalışma ile benzerlik göstermektedir. Yaban domuzu gün boyu güneș alan güney bakılara nazaran günün saatlerine göre değişen gölgelik alanlarda aktivitesini daha çok sürdürmektedir. Domuzun kuzey bakıları tercih etmemesinin nedeni diğer bakılara göre daha soğuk alanlar olmasıdır, bundan dolayı domuza ait iz ve belirtiler bu bakılarda fazla rastlanmamıştır.

Abaigar vd. (2009)'nin çalıșmasına göre domuzun beslendiğ $i$ yerdeki izlerinden hareketle belirtilerin Multivaryasyon ve Ki-Kare Testi Analizlerine göre meşelik ve karışık ormanlan tercih ettiği, dere vejetas yonunu sadece beslenmek için indiğini belirtmiștir. Bizim yaptığımız Yaban domuzu için yapılan Sperman Korelasyon Analizi ve Ki-Kare Testi sonuçlarına göre, Sedir ormanı ve Kayalık alanlar önemli çıkmıştır. Sedir ormanlarını domuzun tercihi korelasyon katsayıs inda pozitif yönde iken, Kayalık alanlara korelasyon katsayısı negatif yönde çıkmıștır. Yani Sedir ormanların 1 domuzun tercih ettiği, kayalık alanlardan uzak durduğu analizlerde görülmektedir. Yaban domuzu istatistikî sonuçlar, Nispi Kullanım İndisi sonuçları ile örtüşmektedir.

\section{Sonuç ve öneriler}

Gölcük Tabiat Parkı'nda rekreasyon ihtiyacı dolayısıyla insan aktivitesinin en yoğun göl kenar şeridinin yaban domuzu tarafindan daha fazla kullanılması isteniyorsa, bu kısma gece belli bir saatten sonra insan girişinin yasaklanması düşünülebilir.

Tabiat parkı içinde derelerin kuru dere olması, domuzun bu bölgeleri tercihinin az olduğunu göstermekte, şayet domuzun bu gibi alanları kullanması isteniyorsa Uzun Devreli Gelişme Planı'nda mevcut kuru derelerin ıslahına gidilmelidir, içme suyu için yer altına döşenen boruların havza yönetim şekline göre havza çıkışından alınması hem Isparta yöresinin su ihtiyacını karşılayacağı gibi hem de domuzun bu alanlardaki varlığını arttıracaktır. Ayrıca Darı Deresi üzerine yapılan barajın kapladığ 1 alan, tahrip ettiğ $i$ vejetasyon ve insan aktivitesi, domuzun bu alandan uzaklaşmasına neden olduğundan mevcut barajdan yan kuru derelere kanallarla fazla suyun aktarılması domuzun yeni yaşam ortamları kazanmas ına sağlayacaktır.

Tabiat Parkı'nın sık kermes meşesi ile kaplı olup domuzun hareketini kısıtlayan alanların yer aldığı Darı Deresi kesiminde yer yer seyreltme çalışmaları yapılacak olursa, bu aralamalar domuzun habitatları daha rahat kullanmasını sağlayacak, popülasyonun bu kesime yönelmesini ve tercih oranını artıracaktır.

Yaban domuzunun Yalanc1 Akasya ormanını yazın tercih ettiği görülmektedir. Bunun nedeni domuzun beslendiği ot, solucan, sümüklüböcek vb. gibi besin kaynağının olması ve bu alanların diğer alanlara göre daha nemli olmasıdır. Yine orman içi açıklıkları her mevsim tercih ettiği görülmektedir. Bu da ormanın kuruluşunda tek meşcere yerine grup küme halinde diğer türlerle karıştırılması, besin niteliğindeki tohumlu bitkiler ve çalıların karıştırılması ve yine yer yer orman içi açıklıkların verilmesi popülasyonların habitat isteklerini karşılayacağını ifade eder. $\mathrm{Bu}$ da yazın tarım arazilerine zarar veren yaban domuzunun bu alanları tercih isteğini azaltacaktır. Çünkü habitat istekleri yakınında olacaktır. Yine kayalık arazilerde tercihini arttırmak için bu alanların bitki vejetasyonu bakımından zenginleştirilecek uygun türler getirilerek yaban domuzunun yaşam alanı geniş letilebilir.

Hem frekans hem de istatistiksel analizlerde sedir ormanının önemli çıkmasının sebeplerinden biri sedir ormanının sık yapraklı ibreli tür olması ve bu yapraklı yapıyı yıl boyunca barındırması, domuzun isteği olan gölgelik alanları sürekli karşılamaktadır. Alanda bundan sonra yapılacak ağaçlandırma çalışmalarında sedir gibi türlere yer vermek domuzun varlığını arttırıcı yönde etki edebilir. Yaban domuzunun habitat tercihinin bazı alanlarda düşük çıkmasının sebepleri arasında yukarıda da belirttiğimiz gibi rekreasyon faaliyetleri, mevcut su ağlarının Isparta'ya götürülmesi ve habitatın yaban domuzu için yeterince gizlenme ve besin olanağ 1 sağlayamamasıdır. $\mathrm{Bu}$ etkenlerin yeniden gözden geçirilip düzenlenmesi gerekmektedir. Ayrıca TP'nın Is parta iline yakın olasından dolayı ve alanda kaçak avcıllğında aşırı olması mevcut popülasyonu tehdit etmekte ve çoğalmasını engellemektedir. Bunun için TP'da av koruma denetimlerinin arttırılması, TP'na birden fazla olan giriş lerin rekreasyon faaliyetlerini artırdığ1 düşünüldüğünde bu girişlere de görevlilerin yerleştirilmesinin kaçak avc1lığın önüne geçilmesine yardımcı olacağı açıktır. 


\section{Kaynaklar}

Abaigar, T., Del Barrio, G.,Vericad, J.R., 2009. Habitat preference of wild boar (Sus scrofa L., 1758) in a mediterranean environment. Indirect Evaluation by Signs, Mammalia, 58(2), 201-210.

Anonim, 1986. Türkiye'de Av ve Yaban Hayat1, Hunting and Wildlife In Turkey, 1986, Türkiye Cumhuriyeti, Tarım Orman ve Köyişleri Bakanlığ , Orman Genel Müdürlüğ̈̈, Printed in the Gelişim Matbaası, Ankara, 712.

Beşkardeş, V., Yılmaz, E., Tamer, Ö., 2010. Evaluation on management of wild boar (Sus scrofa L.) population in Bolu-Sazakici hunting ground. Journal of Environmental Biology, January 2010, 31, 207-212.

Dardaillon, M., 1986. Seasonal variations in habitat selection and spatial distribution of wild boar ( $\mathrm{Sus}$ Scrofa) in the Camargue, Southern France. Behavioural Processes, 13(3), 251-268.

Doğa Koruma Milli Parklar Genel Müdürlüğü (DKMGM), 2012. Genel Bilgiler, Erişim Tarihi: 03.12.2012, http://www.milliparklar.gov.tr/AnaSayfa.aspx?sflang=tr

Fonseca, C., 2007. Winter habitat selection by wild boar Sus scrofa in southeastern Poland, European Journal of Wildlife Research, May 2008, 54(2), 361-366.

Gündoğdu, E., 2004. Yaban Hayatında Habitat Envanteri. Süleyman Demirel Üniversitesi Orman Fakültesi Dergisi, Is parta, A1, 73-83.

Hızal. E., 2007. Kapıdağ yarımadası yaban hayatı koruma alanı memeli (Mammalia) faunas1. İstanbul Üniversitesi, Fen Bilimleri Enstitüsü, Doktora Tezi, 179s, İstanbul

Isparta İl Çevre ve Orman Müdürlüğü Arşivi, 2006 (IIÇOM). Gölcük Tabiat Parkı, UDGP, Analitik Etüt ve Sentez Raporu, Isparta.

Isparta İl Çevre ve Orman Müdürlüğü Arşivi, 2007 (IIÇOM). Editör, Tuzcu, D., Isparta Çevre Durum Raporu, Isparta

Isparta İl Çevre ve Orman Müdürlüğü Arşivi, 2010 (IIÇOM), Isparta.

IUCN Red List (IUCN), 2013, Lepus capensis. Erişim Tarihi:11.01.2013, http://www.iucnredlist.org/details/41277/0

Kayaöz, Erkan., 2001, Çilingoz yaban hayatı koruma sahas1 etüt-envanter uygulama projesi. Avgünü Dergis i, Ankara $62,43-46$.
Kırmıt, G., 1991. Av hayvanlarının tanıtımı. Tarım Orman ve Köyiş leri Bakanlığ1 Dergisi TOK, 66, 7-8.

Leaper, R., Massei, G., Gorman, M.L., Aspinall, R., 1999. The Feasibility Of Reintroducing Wild Boar (Sus scrofa) to Scotland. Mammal Review.

Kultur, 2010. Erişim tarihi 09.04.2010, http://www.kultur. gov.tr

Küçük, Ö., Uslu, Ö., 2004. Sinop Bozburun yaban hayat1 koruma alanında yaban domuzu (Sus scrofa L.) sayımı. Gazi Üniversitesi, 4(1), 45-56.

Oğurlu, İ., 1992. Çatacık koruma-üretme sahasında geyik (Cervus elaphus L.) popülasyon ekolojisi üzerine araştırmalar. KTÜ. Fen Bilimleri Enstitüsü, Doktora Tezi, 251s, Trabzon.

Oğurlu, İ., 2001. Yaban Hayatı Ekolojisi. Süleyman Demirel Üniversitesi, 17, 220s. Isparta.

Oğurlu, İ., 2003. Yaban Hayatında Envanter. T.C., Çevre ve Orman Bakanlığı, Doğa Koruma ve Milli Parklar Genel Müdürlüğ̈̈, 207s, Is parta.

Oğurlu, İ., 2008. Yaban hayatı kaynaklarımızın yönetimi üzerine. Süleyman Demirel Üniversitesi Orman Fakültesi Dergisi, A2, 35-83.

Oğurlu, İ., Gündoğdu, E., Sarıkaya, O., 2005. Gölcük tabiat park1 faunas1 üzerine gözlemler. Korunan Alanlar Sempozyumu Sözlü Bildiriler Kitab1, SDÜ, Isparta 615621.

Oğurlu, İ., Ünal, Y., 2011. Yaban hayatı çalışmalarında üniversite, yerel halk ve kamu işbirliği: Isparta Aksu örnek avlağında yaban domuzu envanteri. SDÜ Orman Fakültesi Dergisi, 12: 7-12

Orman ve Su İşleri Bakanlığ1 6. Bölge, 2012 (OSB 6. Bölge), Genel Bilgiler, Erişim Tarihi:03.12.2012, http://bolge6.ormansu.gov.tr/6bolge/AnaSayfa/ tabiatparklari.aspx?sflang $=$ tr

Orman ve Su Bakanlığı(OSB), 2013. MAK Kararları, Erişim Tarihi: 19.01.2013, http://www.ormansu.gov.tr/osb/Libraries/Dokümanlar/2 0120607-5.sflb.ashx.

Thurfjell, H., Ball, J.P., Ahle'n, P.A., Kornacher, P., Dettki, H.\&Sjoberg,K. 2009: Habitat use and spatial patterns of wild boarSus scrofa (L.): agricultural fields and edges. European Journal ofW ildlife Research 55(5): 517-523.

Ünal, Y., 2011. Isparta- Yazılıkaya'da Av-Yaban Hayatı Envanteri. Doktora Tezi, SDÜ, Fen Bilimleri Enstitüsü, 172s., Isparta. 